University of Windsor

Scholarship at UWindsor

2009

\title{
CEO Compensation Structure following Succession: Evidence of Optimal Incentives with Career Concerns
}

\author{
Eahab Elsaid \\ University of Windsor \\ Wallace N. Davidson III \\ Bradley W. Benson
}

Follow this and additional works at: https://scholar.uwindsor.ca/odettepub

Part of the Business Commons

\section{Recommended Citation}

Elsaid, Eahab; Davidson III, Wallace N.; and Benson, Bradley W.. (2009). CEO Compensation Structure following Succession: Evidence of Optimal Incentives with Career Concerns. Quarterly Review of Economics and Finance, 49 (4), 1389-1409.

https://scholar.uwindsor.ca/odettepub/40

This Article is brought to you for free and open access by the Odette School of Business at Scholarship at UWindsor. It has been accepted for inclusion in Odette School of Business Publications by an authorized administrator of Scholarship at UWindsor. For more information, please contact scholarship@uwindsor.ca. 


\title{
CEO compensation structure following succession: Evidence of optimal incentives with career concerns
}

\author{
Eahab Elsaid $^{\mathrm{a}, 1}$, Wallace N. Davidson III ${ }^{\mathrm{b}, 2}$, Bradley W. Benson ${ }^{\mathrm{c}, *}$ \\ a Accounting and Finance Department, University of Windsor, Windsor, ON N9B 3P4 Canada \\ b Finance Department - Mailcode 4626, Southern Illinois University, Carbondale, IL 62901, United States \\ c Department of Economics and Finance, College of Business, Louisiana Tech University, Ruston, LA 71272, United States
}

\section{A R T I C L E I N F O}

\section{Article history:}

Received 14 January 2009

Received in revised form 7 July 2009

Accepted 11 August 2009

Available online $\mathrm{xxx}$

\section{JEL classification:}

G14

G34

J33

M52

\section{Keywords:}

CEO succession

CEO compensation

Managerial incentives

Managerial labor market

\begin{abstract}
A B S T R A C T
To motivate managers to pursue shareholder interests, boards may design management compensation packages to reward managers for good firm performance. However, Gibbons and Murphy (1992) note that when CEOs are far from retirement, they have career concerns. In these cases, Gibbons and Murphy argue that it may not be optimal for their current compensation to be too dependent on firm performance. Testing this proposition, we find that abnormal returns are negatively related to the percentage of performancebased pay of newly hired CEOs when companies announce CEO successions. Since these newly hired CEOs are likely some distance from retirement, we interpret these results as being consistent with Gibbons and Murphy; it may be better to allow newly hired CEOs to be paid in human capital increases from the managerial labor market than to have their current pay too closely related to performance.
\end{abstract}

(c) 2009 The Board of Trustees of the University of Illinois. Published by Elsevier B.V. All rights reserved.

\section{Introduction}

Agency problems exist in modern corporations because the goals and desires of managers may not be consistent with those of shareholders. Managers, as a result, may not always use the firm's

\footnotetext{
* Corresponding author. Tel.: +1 3182572389.

E-mail addresses: elsaid@uwindsor.ca (E. Elsaid), davidson@cba.siu.edu (W.N. Davidson III), bbenson@latech.edu (B.W. Benson).

1 Tel.: +1 519253 3000x4258.

2 Tel.: +1 6184531429 .
}

1062-9769/\$ - see front matter @ 2009 The Board of Trustees of the University of Illinois. Published by Elsevier B.V. All rights reserved. doi:10.1016/j.qref.2009.08.004

Please cite this article in press as: Elsaid, E., et al. CEO compensation structure following succession: Evidence of optimal incentives with career concerns. Quarterly Review of Economics and Finance (2009), doi:10.1016/j.qref.2009.08.004 
capital in a manner that maximizes shareholder welfare. Governance mechanisms have evolved to help align manager interests with those of shareholders. There are both internal and external governance mechanisms. Our focus is on the effectiveness of one internal governance mechanism, the design of manager pay packages for newly hired CEOs. Jensen and Murphy (1990) point out that it is more important how you pay managers and less important how much they are paid. Pursuant to this view, optimal contracting exists when compensation motivates managers to pursue shareholder wealth maximization as the firm's primary goal.

Gibbons and Murphy (1992), however, argue that career concerns for managers can affect the importance of incentive contracts. In the presence of career concerns, the optimal incentive contract is a combination of the implicit incentives from career concerns and the explicit incentive from the compensation contract. Career concerns are strongest when a CEO is farther from retirement; this is likely the situation for most newly hired CEOs. In these cases, it may be optimal for current pay to be less dependent upon performance because career concerns such as remaining competitive in the managerial labor market may provide sufficient motivation. However, when a manager is nearing retirement, the importance of career concerns fades. Here, motivation may need to come from elsewhere such as from incentive-based pay.

Using a sample of 619 succession announcements between the years of 1991 and 2005, we test the Gibbons and Murphy (1992) model by comparing the succession announcement period abnormal returns to the compensation packages of successor CEOs. We find results consistent with the Gibbons and Murphy model; although the market reacts positively to succession announcements, CEO succession announcement period abnormal returns are negatively related to the percentage of performance-based pay for successor CEOs. In other words, the stock market reacts less positively to contracts with considerable performance-based pay for new CEOs whose career concerns should be high.

We organize the remainder of this paper as follows. Section 2 provides a discussion of optimal incentive structure of CEO pay contracts. Section 3 describes our data and presents summary statistics. Section 4 examines the cross-sectional relation between changes in CEO compensation structure surrounding succession events and the returns that accompany the release of new information about CEO succession. Section 5 investigates how changes in CEO compensation structure relate to the career concerns of the CEO. Section 6 presents robustness tests. Finally, Section 7 concludes.

\section{Optimal incentive structure with career concerns}

\subsection{Agency problems and compensation}

When managers do not operate firms to maximize shareholder wealth, costly agency problems result. To mitigate agency problems there are both external (e.g. takeovers and proxy fights) and internal solutions. One internal solution is a compensation plan that links management's compensation to the firm's performance. ${ }^{3}$ However, designing a plan that aligns CEO interests with that of shareholders is difficult, and if it is poorly designed, it may lead to managerial entrenchment and poor performance.

There has been considerable research on the design of CEO compensation packages. Morgan and Poulsen (2001) find that compensation plan announcements that align managerial compensation to shareholder interests are associated with positive abnormal returns. Thus, shareholders seem to benefit when their CEO's compensation depends on company performance.

CEOs may prefer to be paid in a less risky manner with pay not dependent on performance. When insiders are on the compensation committee, managerial compensation is not as closely linked to shareholder wealth (Newman \& Mozes, 1999). Entrenched CEOs may bias their compensation structure towards low risk components that are not influenced by performance (Toyne, Millar, \& Dixon, 2000).

\footnotetext{
${ }^{3}$ There is not complete agreement on this point. For example, Bebchuk and Fried (2004) posit that boards do not negotiate with CEOs at arms-length; they maintain that powerful managers can heavily influence their own pay.
} 


\subsection{Career concerns}

CEO career concerns complicate the pay-for-performance debate. CEOs are paid both in current compensation and also with increases in their human capital. Nohel and Todd (2005) argue that human capital is the present value of all future compensation gains or losses that are attributed to the manager's job performance. Managers that make good decisions, ones that increase shareholder wealth, can be rewarded with current compensation and also an increase in their human capital. That is, in the managerial labor market, managers that perform well will be rewarded with future increases in income and managers that perform poorly will not be rewarded. As a result, career concerns can help to alleviate agency problems because they help to align manager and shareholder interests (Fama, 1980; Holmstrom, 1982).

There is empirical evidence supporting the idea of human capital rewards. Hong and Kubik (2003), for example, find that security analysts that are good at forecasting company earnings are rewarded by either moving to more prestigious brokerage houses with greater pay or by being assigned to cover more important stocks in their own brokerage house. Brickley, Linck, and Coles, 1999 find that the likelihood of a retired CEO remaining on his company's board or serving on other boards is dependent upon the firm's financial performance while CEO.

Since CEOs are compensated with either current compensation or for increases in their human capital, which form of compensation would be optimal? Gibbons and Murphy (1992) propose that increases in human capital based on future compensation will be more important early in an executive's career. For executives closer to retirement, concern for increases in human capital will be less important. They state:

Accordingly, in the presence of career concerns, the optimal compensation contract optimizes total incentives-the combination of the implicit incentives from career concerns and the explicit incentives from the compensation contract. Because the implicit incentives from career concerns are weakest for workers close to retirement, explicit incentives from the optimal compensation contact should be strongest for such workers; for young workers, it can be optimal for current pay to be completely independent of current performance (p. 469).

\subsection{Succession and career concerns}

Since CEOs want low risk compensation and shareholders would likely prefer a CEO compensation structure that reduces agency problems, the divergence must be resolved by negotiations between the board and the CEO. A board may find it difficult to restructure an incumbent CEO's contract due to inertia, complacency, and the CEO's influence over the board and the compensation committee. Unless a sitting CEO is unhappy with the current contract, the CEO may use this influence to either stall the renegotiation process or to redesign the pay package to reflect the CEO's own interests. Changing the compensation package with the incumbent CEO may be difficult, bring conflict between the CEO and the board, and will certainly involve difficult negotiation. However, when a CEO succession takes place, the board has an opportunity to make changes without conflict with a possibly powerful incumbent CEO. Examining compensation for successor CEOs provides an opportunity to avoid the problems that may occur when examining incumbent CEO compensation.

The successor CEO is new to the position and is likely a few years away from retirement. Following the logic in Gibbons and Murphy (1992), it may not be optimal to align pay to performance too closely when a CEO is newly hired. We propose that when companies design the successor CEO compensation contract with considerable pay-at-risk the market will react more negatively to the announcement because career concerns are strong for most newly hired CEOs. In the presence of high career concerns, there is less need for a large pay-at-risk component in the successor compensation contract. Thus, the primary (career concerns) hypothesis of our paper is as follows:

H1. Abnormal returns are negatively related to the percentage of performance-based pay of younger successor CEOs when companies announce CEO successions. 


\subsection{Retention and career concerns}

The alternative hypothesis is that a higher percentage of equity compensation is used by firms for retention reasons, rather than to resolve potential agency issues through incentive alignment (Oyer \& Schaefer, 2003, 2005). For example, when an executive leaves for another company, this decision will be partially influenced by the costs of leaving a current employer. Although not the only cost incurred by an executive, a primary monetary cost is the forfeiture of unvested equity compensation. ${ }^{4}$ However, new employers may reimburse executives for the monetary losses incurred by leaving a current employer through either one-time equity grants or in higher future compensation. Still, the greater the forfeiture amount involved, the less likely the new employer may be to "make the executive whole" by reimbursing him for the full value of lost equity compensation. Thus, current employers justify high levels of equity-based compensation as a means to deter other potential employers from hiring away key executives. This is especially true for more highly valued executives, such as CEOs.

The limited empirical research on this issue appears to support the retention justification for high levels of equity compensation. Mehran and Yermack (1999), for example, find that option compensation is inversely related to turnover. Similarly, Balsam and Miharjo (2007) find that the value of unexercisable in-the-money options and restricted shares is also inversely related to voluntary executive turnover. Furthermore, Chidambaran and Prabhala (2003) examine the repricing of existing options, a practice which is partially justified by firms for retention reasons. They find that the exclusion of the CEO in the repricing is likely to be associated with CEO departure.

However, while equity compensation may serve to increase the retention of executives, it is reasonable to expect that it may have varying effects on executives at different points during their career. For example, younger executives may be more willing to forfeit unvested equity compensation when taking a new position because they have more years to recover any lost amounts. Thus, equity compensation may be less effective as a retention tool in younger executives. As a result, the optimal contract under the retention hypothesis would include a higher percentage of equity-based compensation for the successor CEO when he is hired, relative to the predecessor.

We propose that, if considering retention issues is truly the best solution from an internal contracting standpoint, then we would expect the market to react more positively to succession announcements that have larger pay-at-risk for the successor because high level of pay-at-risk compensation is inversely related to executive turnover. The market will react positively to the firm's attempts at retaining its top management and talent. However, this method may not be ideal when dealing with young successor CEOs. Thus, the alternative (retention) hypothesis of our paper is as follows:

H2. Abnormal returns are positively related to the percentage of performance-based pay of older successor CEOs when companies announce CEO successions.

\section{Data and summary statistics}

To study the changes in CEO compensation structure surrounding CEO succession events, we identify CEO succession announcements from a LexisNexis search for the years of 1991-2005. We match this data with data from the Execucomp database. Execucomp provides data on salary, bonus, option grants, and total compensation for the top five executives (ranked annually by salary and bonus) for firms in S\&P 500, S\&P Midcap 400 and S\&P Smallcap 600. To minimize the influence of other factors in our analysis of optimal incentive structure with career concerns, we limit our sample to successions that occur following voluntary turnover. ${ }^{5}$ To determine the type of succession, we examine the column "REASON" in the Execucomp database, which explains why the named CEO left the company. It provides four different reasons: resigned, retired, deceased, or unknown. We verified the reason listed

\footnotetext{
${ }^{4}$ Additional monetary costs incurred by an executive include such things as a pension plan with payout structures tied to years of service. Other costs include relocation costs, such as moving expenses and the sale of a home.

${ }^{5}$ Forced successions may change the dynamics of the negotiation process between successor CEOs and their boards. Hence we delete them from the sample to avoid any problems they may bring to the study.
} 
in Execucomp by searching the Wall Street Journal Index (WSJI) and the Wall Street Journal (WSJ) for the reasons for the succession. From the news stories, we classify voluntary successions as all CEO successions arising from retirement (CEOs over age 60), ${ }^{6}$ death, illness, or those involving the CEO's departure for a better and more prestigious position in another firm. Our final sample includes 619 succession announcements between the years of 1991 and 2005.

\subsection{Cumulative abnormal returns}

To determine the stock market's reaction to announcements of CEO succession announcements we utilize event methodology. We define day 0 to be the succession announcement date. We use the single index market model to predict returns:

$$
R_{i t}=\alpha_{i}+\beta_{i}\left(R_{m t}\right)+e_{i t}
$$

where $R_{i t}=$ the return on security i at time $t ; \alpha_{i}=$ the estimated intercept for security $i$ 's regression equation; $\beta_{i}$ = the estimated slope for security $i$ 's regression equation; $R_{m t}=$ the return on the market at time $t$ as proxied by the equally weighted index available from CRSP; and $e_{i t}=$ the error term from the regression for company $i$ at time $t$.

We estimate the regression over the period -120 to -31 relative to the announcement date, day 0 . We then obtain the abnormal return for security $i$ at time $t$ as follows:

$$
A R_{i t}=R_{i t}-\left(\alpha_{i}-\beta_{i} R_{m t}\right)
$$

We compute abnormal returns from day -30 to day +30 . We compute the cumulative abnormal return for security $i, C A R_{i}$, over various intervals $T_{1 i}$ to $T_{2 i}$ as

$$
C A R_{i}=\sum_{t=T_{1 i}}^{T_{2 i}} A R_{i t}
$$

For a sample of $N$ securities we obtain the mean cumulative abnormal return, $C A R$, as

$$
C A R=\frac{\sum_{i=1}^{N} C A R_{i}}{N}
$$

If there is no abnormal stock price movement, then the CAR would be zero. To test if the CAR are nonzero, we use the Patell $Z$-statistic. We also count the number of positive and negative $C A R_{i}$ and use a generalized $Z$-statistic to determine if the number of positive $C A R_{i}$ is different from the expected value. The expected value would be $50 \%$ positive and $50 \%$ negative in the absence of abnormal performance.

Table 1 contains the CAR estimates for various intervals around the CEO succession announcements. We compute abnormal returns for this group of firms centered on the CEO succession announcement day, day 0 . Over the interval, -1 to +1 , the $C A R$ is $0.93 \%$. Its $Z$-statistic is 6.440 which is statistically significant at the 0.001 level. Over this interval, there are 358 positive $C A R_{i}$ and 261 that are negative. The $Z$-statistic for the generalized sign test is 5.042 (significant at the 0.001 level) and suggests that the number of positive $C A R_{i}$ did not occur by chance. The $C A R$ on day 0 is $0.42 \%$. Its Z-statistic is 5.345 which is statistically significant at the 0.001 level. In addition, on this day, the number of positive $C A R_{i}$ is 339 and 280 are negative. The $Z$-statistic for the generalized sign test is 3.513 which is significant at the 0.001 level. The number of positive $C A R_{i}$ is unlikely to have occurred by chance.

Under current reporting standards, firms have 4 days to report material changes in a named executive officer's employment contract in an 8-k filing. Since information about compensation might not be released for a few days after the succession announcement, we also report results for the interval

\footnotetext{
${ }^{6}$ We consider the age 60 to be the normal retirement age for a CEO as in Parrino (1997). However, in additional unreported tests we use age 65 as the normal retirement age. There are 208 CEOs between the ages of 60 and 65 in our sample. Nevertheless, the results are similar when using age 65 .
} 
Table 1

Cumulative abnormal returns for voluntary CEO succession announcements.

\begin{tabular}{lllllc}
\hline Days & $N$ & Cumulative abnormal return & Positive:negative & Patell $Z$ & Generalized sign $Z$ \\
\hline$(-30,+30)$ & 619 & $1.74 \%$ & $329: 290$ & $2.501^{* *}$ & $2.709^{* *}$ \\
$(-30,-2)$ & 619 & $0.40 \%$ & $330: 289$ & 0.577 & $2.789^{* *}$ \\
$(-5,-2)$ & 619 & $-0.11 \%$ & $293: 326$ & -0.762 & -0.188 \\
$(-1,0)$ & 619 & $0.54 \%$ & $359: 260$ & $5.154^{* * *}$ & $5.123^{* * *}$ \\
$(-1,+1)$ & 619 & $0.93 \%$ & $358: 261$ & $6.440^{* * *}$ & $5.042^{* * *}$ \\
$(0,+5)$ & 619 & $0.93 \%$ & $326: 293$ & $4.432^{* * *}$ & $2.467^{* *}$ \\
$(-1)$ & 619 & $0.13 \%$ & $310: 309$ & $1.944^{*}$ & 1.180 \\
$(0)$ & 619 & $0.42 \%$ & $339: 280$ & $5.345^{* * *}$ & $3.513^{* * *}$ \\
$(+1)$ & 619 & $0.38 \%$ & $298: 321$ & $3.866^{* * *}$ & 0.214 \\
\hline
\end{tabular}

"Days" represents the number of days before and after the CEO succession announcement day (day 0 ). " $N$ " represents the number of CEO succession announcements. "Cumulative abnormal return" represents the cumulative abnormal stock price movement around the CEO succession announcement day. "Positive:negative" represents the number of positive to negative cumulative abnormal returns around the CEO succession announcement day. Patell $Z$-statistic is used to test if the cumulative abnormal returns are non-zero. Generalized $\operatorname{sign} Z$ is used to determine if the number of positive cumulative abnormal returns is different from the expected value.

* Indicate statistical significance at the 0.05 level, using a 1-tail test.

** Indicate statistical significance at the 0.01 levels, using a 1 -tail test.

*** Indicate statistical significance at the 0.001 level, using a 1-tail test.

0 to +5 . The abnormal return over this interval is $0.93 \%$ and is significant at the 0.001 level. ${ }^{7}$ Overall, our results are consistent with the explanation that the market values these successions positively.

\section{2. $C E O$ and firm characteristics}

We have proposed that when a CEO leaves an organization and the board appoints a successor, the board has an opportunity to restructure the contract in an optimal manner. How much change occurs from the predecessor's contract will likely depend on many factors, and it may be necessary to control for how these other factors influence the returns that accompany the release of new information about CEO changes. We group these factors into CEO compensation characteristics, CEO characteristics, board characteristics, and firm characteristics. We examine the changes in these factors around CEO succession within the same firm. Thus, we are able to control for firm-specific characteristics.

\subsubsection{CEO compensation characteristics}

We examine the various components of compensation surrounding the succession for both the predecessor and the successor (i.e. years -1 and +1 ). As a result, the compensation for the predecessor is measured in the fiscal year prior to the succession year and the compensation for the successor is measured as of the fiscal year following the succession year. We ignore the transition year (i.e. year 0) since the transition year compensation data may include partial year compensation or compensation for those individuals holding positions other than CEO within the firm during the year. In addition, year 0 compensation may include extra compensation for the successor CEO for lost options at their old firm and may contain departure compensation for the predecessor CEO.

As shown in Table 2 , we observe that the average percentage of equity-based pay for successors is $35.57 \%$, while the average for predecessors is $25.17 \%$, representing an average increase of approximately $10.39 \%$ in equity-based compensation for the incoming CEO. However, we also observe from Table 2 that this difference is $5.12 \%$ less for firms with a positive CAR. ${ }^{8}$ This result supports the career concerns hypothesis. In both cases, the difference in percentage of equity-based pay is significant.

\footnotetext{
${ }^{7}$ Firms often file their 8-k within a shorter period of time. For robustness we also rerun our regression results using the CAR for a 6-day announcement window (days 0 to +5 ). Our conclusions are unchanged and are reported in Appendix A.

8 The difference is approximately $12.57 \%$ less for firms in the lowest CAR quartile versus those in the highest CAR quartile. 
Table 2

Sample statistics.

\begin{tabular}{|c|c|c|c|c|c|c|c|c|c|}
\hline \multicolumn{10}{|l|}{ Panel A: all successions } \\
\hline \multirow[b]{2}{*}{ Variable } & \multirow[b]{2}{*}{$N$} & \multicolumn{3}{|l|}{ Successor } & \multicolumn{3}{|c|}{ Predecessor } & \multirow[b]{2}{*}{ Difference } & \multirow[b]{2}{*}{$t$-Statistic } \\
\hline & & Mean & Median & s.d. & Mean & Median & s.d. & & \\
\hline Restricted Stock \% & 583 & $5.28 \%$ & $0.00 \%$ & $13.41 \%$ & $3.94 \%$ & $0.00 \%$ & $12.37 \%$ & $1.34 \%$ & $1.99^{* *}$ \\
\hline Stock Options \% & 583 & $30.29 \%$ & $26.09 \%$ & $29.78 \%$ & $21.23 \%$ & $4.25 \%$ & $26.77 \%$ & $9.06 \%$ & $6.30^{* * *}$ \\
\hline Equity-Based Compensation \% & 583 & $35.57 \%$ & $33.64 \%$ & $30.50 \%$ & $25.17 \%$ & $16.21 \%$ & $27.69 \%$ & $10.39 \%$ & $7.07^{* * *}$ \\
\hline Increase in Equity Comp. \% (Successor) $=1$ & 583 & $55.57 \%$ & $100.00 \%$ & $49.73 \%$ & - & - & - & - & - \\
\hline Equity-Based Compensation $\$(000)$ & 583 & 1734.19 & 389.53 & 7087.18 & 787.07 & 124.93 & 1892.22 & 947.12 & $3.21^{* * *}$ \\
\hline Total Compensation $\$(000)$ & 583 & 3004.61 & 1565.73 & 7844.26 & 891.22 & 666.95 & 724.47 & 2113.40 & $6.58^{* * *}$ \\
\hline CEO Age & 583 & 51.17 & 51.00 & 6.69 & 59.98 & 61.00 & 7.68 & -8.81 & $-21.80^{* * *}$ \\
\hline CEO Tenure (Predecessor) & 583 & - & - & - & 9.83 & 7.50 & 8.48 & - & - \\
\hline CEO is Outsider (Successor) $=1$ & 583 & $22.98 \%$ & $0.00 \%$ & $42.11 \%$ & - & - & - & - & - \\
\hline CEO Duality $=1$ & 583 & $27.27 \%$ & $0.00 \%$ & $44.57 \%$ & $73.76 \%$ & $100.00 \%$ & $44.03 \%$ & $-46.48 \%$ & $-16.39^{* * *}$ \\
\hline \% Outside Directors & 583 & $62.13 \%$ & $63.64 \%$ & $17.07 \%$ & $62.45 \%$ & $64.29 \%$ & $17.38 \%$ & $-0.32 \%$ & -0.86 \\
\hline Board Size & 583 & 9.95 & 10.00 & 2.83 & 10.03 & 10.00 & 2.97 & -0.08 & -1.32 \\
\hline \# Board Meetings & 583 & 7.71 & 7.00 & 2.99 & 7.25 & 7.00 & 3.05 & 0.46 & $4.17^{* * *}$ \\
\hline Outside Director Tenure & 583 & 48.53 & 45.00 & 32.17 & 50.32 & 46.00 & 33.99 & -1.79 & $-3.04^{* * *}$ \\
\hline \% Outside Directors on Comp Comm. & 583 & $86.25 \%$ & $100.00 \%$ & $21.07 \%$ & $85.39 \%$ & $100.00 \%$ & $21.96 \%$ & $0.86 \%$ & 1.34 \\
\hline Comp Comm. Size & 583 & 3.74 & 4.00 & 1.42 & 3.69 & 4.00 & 1.47 & 0.05 & 1.23 \\
\hline \# Comp Comm. Meetings & 583 & 4.03 & 4.00 & 2.40 & 3.74 & 3.00 & 2.41 & 0.29 & $3.32^{* * *}$ \\
\hline Board Strength & 583 & 0.00 & 0.05 & 0.87 & 0.00 & 0.10 & 0.89 & 0.00 & 0.00 \\
\hline Total Assets (Mil) & 583 & 3907.63 & 1074.92 & 8250.10 & 3543.61 & 889.58 & 7832.01 & 364.03 & $5.24^{* * *}$ \\
\hline Leverage (\%) & 583 & $24.83 \%$ & $23.68 \%$ & $22.04 \%$ & $23.88 \%$ & $23.43 \%$ & $18.46 \%$ & $0.95 \%$ & 1.50 \\
\hline Ind. Adj. ROA & 583 & 1.42 & -0.02 & 77.76 & -2.05 & 0.09 & 31.95 & 3.47 & 1.00 \\
\hline Tobin's $Q$ & 583 & 0.25 & 0.25 & 0.60 & 0.21 & 0.23 & 0.34 & 0.04 & $2.57^{* *}$ \\
\hline
\end{tabular}


Panel B: split by CAR $(-1,+1)$

\begin{tabular}{|c|c|c|c|c|c|c|c|c|}
\hline \multirow[b]{3}{*}{ Variable } & \multicolumn{3}{|c|}{ Split by $-/+$ CAR $(-1,+1)$} & \multicolumn{5}{|c|}{ Split by quartiles: CAR $(-1,+1)$} \\
\hline & \multicolumn{2}{|c|}{ Difference } & \multirow[b]{2}{*}{ F-Statistic } & \multicolumn{4}{|l|}{ Difference } & \multirow[b]{2}{*}{ F-Statistic } \\
\hline & Negative & Positive & & Low & 2nd low & 2nd high & High & \\
\hline Restricted Stock \% & $3.17 \%$ & $0.02 \%$ & $5.41^{* *}$ & $3.19 \%$ & $2.50 \%$ & $1.24 \%$ & $-1.62 \%$ & $2.49^{*}$ \\
\hline Stock Options \% & $10.21 \%$ & $8.23 \%$ & 0.46 & $11.97 \%$ & $7.60 \%$ & $12.24 \%$ & $4.21 \%$ & 1.78 \\
\hline Equity-Based Compensation \% & $13.37 \%$ & $8.25 \%$ & $2.97^{*}$ & $15.16 \%$ & $10.09 \%$ & $13.48 \%$ & $2.59 \%$ & $3.61^{* *}$ \\
\hline Increase in Equity Comp. \% (Successor) $=1$ & $57.79 \%$ & $53.98 \%$ & 0.83 & $58.90 \%$ & $55.56 \%$ & $58.67 \%$ & $48.95 \%$ & 1.26 \\
\hline Equity-Based Compensation $\$(000)$ & 932.76 & 957.45 & 0.00 & 683.88 & 953.57 & 747.65 & 1418.61 & 0.31 \\
\hline Total Compensation $\$(000)$ & 2275.86 & 1996.46 & 0.18 & 2259.79 & 2035.22 & 1516.51 & 2668.78 & 0.56 \\
\hline
\end{tabular}

The successor compensation variables are measured at year +1 and the predecessor compensation variables are measured at year - 1 ."Restricted Stock \%" represents the CEO restricted stock grants as a percentage of the CEO total compensation. "Stock Options \%" represents the CEO stock option grants as a percentage of the CEO total compensation. "Equity-Based Compensation \%" represents the sum of the CEO restricted stock grants and stock options grants measured as a percentage of the CEO total compensation. "Increase in Equity Comp. \%) (Successor =1)" represents a dummy variable equal to 1 if the successor's compensation contract is composed of a greater percentage of equity-based compensation than that of the predecessor at year +1 for the successor and at year -1 for the predecessor. "Equity-Based Compensation \$ (000)" represents the sum of the CEO restricted stock grants and stock options grants (in thousands of dollars). "Total Compensation $\$(000)$ " represents the sum of the CEO salary, bonus, other annual pay, restricted stock grants, stock option grants and long-term incentive payouts (in thousands of dollars). "CEO Age" represents the CEO age at year 0. "CEO Tenure (Predecessor)" represents the number of years the predecessor held the CEO position. "CEO is Outsider (Successor) =1" represents a dummy variable equal to 1 if the successor is an outsider and equal to 0 otherwise. "CEO Duality= 1 " represents a dummy variable equal to 1 if the CEO holds the title of both CEO and Chairman of the board. The successor board variables are measured at year 0 and the predecessor board variables are measured at year -2 . "\% Outside Directors" represents the number of outside directors serving on the board as a percentage of total directors on the board. "Board Size" represents the number of directors on the board. "\# Board Meetings" represents the number of times the board of directors met. "Outside Director Tenure" represents the sum of the director tenure of all outside directors serving on the board. "\% Outside Directors on Comp Comm." represents the number of outside directors serving on the board as a percentage of total directors on the board. "Comp Comm. Size" represents the number of directors on the compensation committee. "\# Comp Comm. Meetings" represents the number of times the compensation committee met. "Board Strength" is a factor loading variable using factor analysis to combine \% Outside Directors, the inverse of Board Size, \# Board Meetings, Outside Director Tenure, \% Outside Directors on Comp Comm., the inverse of Comp Comm. Size, and \# Comp Comm. Meetings. "Total Assets (Mil)" represents the natural logarithm of the firm's total asset size (in millions of dollars) at year +1 for the successor and at year -1 for the predecessor. "Leverage" represents the firm's leverage at year +1 for the successor and at year -1 for the predecessor. "Ind. Adj. ROA" represents the firm's industry adjusted return on assets at year +1 for the successor and at year -1 for the predecessor. "Tobin's $Q$ " represents the firm's Tobin's $Q$ at year +1 for the successor and at year -1 for the predecessor. "CAR $(-1,+1)$ " represents the CEO succession announcement cumulative abnormal return from day -1 to day +1 .

* Indicate levels of significance of $10 \%$.

** Indicate levels of significance of $5 \%$

**** Indicate levels of significance of $1 \%$. 


\subsubsection{CEO Characteristics}

We obtain data on CEO characteristics from Execucomp and firm proxy statements. The tenure and age of the CEO may determine his or her effectiveness in managing the firm. Alderfer (1986) suggests that top officials with little experience have limited effectiveness because it takes time to gain an understanding of the companies. Older CEOs or those with longer tenure may have a greater understanding of the firm and its industry. This could translate into better firm performance. We calculate predecessor CEO tenure as the difference between the year of the observation and the year in which the executive became CEO. The average CEO tenure of the predecessor CEO is 9.83 years. We calculate the age of both the successor and predecessor CEO as their age in the year of the succession announcement. The average age of the successor is 51.17 years, ${ }^{9}$ while the average of the predecessor in their departure year is 59.98 years. The average difference of 8.81 years between successor CEOs and their predecessors is significant.

We determine whether the successor CEO joined the company from the outside. Outside succession seems to occur more frequently following poor performance (Boeker \& Goodstein, 1993; Cannella \& Lubatkin, 1993; Davidson, Worrell, \& Dutia, 1993; Parrino, 1997). By hiring an outsider, the board may be sending "a signal that a major change is necessary and that no insider can bring the fresh perspective that is required" (Vancil, 1987, p. 57). Accordingly, we set a dummy variable equal to one in cases where the CEO joined the company from the outside. On average, $22.98 \%$ of the CEOs joined the company from the outside.

Finally, we determine whether or not the successor or predecessor CEO holds the title of CEO and chairman, CEO duality. CEO duality may concentrate power in the CEO's position, allowing the CEO to potentially control information available to other board members, which may impede effective monitoring (Jensen, 1993). We create an indicator variable equal to 1 if the CEO also holds the title of Chairman of the Board. On average, 27.27\% of successor CEOs hold the title of CEO and chairman versus $73.76 \%$ of predecessor CEOs. Duality is removed in $58 \%$ of successions, duality remains the same in $31.18 \%$ of succession, and duality is added in $10.82 \%$ of successions.

\subsubsection{Board characteristics}

Board strength can be proxied by several variables. We combine several measures of board strength with a factor analysis as in Elsaid and Davidson (2009) so that we have one board strength variable. Our proxies for board strength that we use in the factor analysis include the percent of independent directors on the board, the percent independent directors on the compensation committee, the average tenure of the independent directors, the size of the board, the size of the compensation committee, the number of board meetings and the number of compensation committee meetings. We measure each of these variables as discussed below.

We use the firm's proxy statements for year -2 and year 0 to determine the composition of the board of directors and compensation committee. We lag the measurement of board composition by 1 year relative to the measurement of CEO compensation because the CEO compensation package is determined during the previous year (Newman \& Mozes, 1999; Sridharan, 1996).

Jensen (1993) argues that smaller boards are more effective monitors of the CEO's actions because large boards place a greater emphasis on "politeness and courtesy", making them easier for the CEO to control. Studies have shown that smaller board size and compensation committee size positively impact firm performance (Yermack, 1996), as well as the number of board and compensation committee meetings (Vafeas, 1999; Xie, Davidson, \& DaDalt, 2003). We measure board size and compensation committee size as the number of directors serving on the board or compensation committee during the year. We determine the number of board and compensation committee meetings, measured as the number of board or compensation committee meetings during the year. We find that the average size of the board of directors for the predecessor CEO and successor CEO are 10.03 and 9.95, respectively. Also, the compensation committee for the predecessor is composed of 3.69 members and the compensation committee for the successor CEO has 3.74 members.

\footnotetext{
${ }^{9}$ The youngest successor was 29 years old and the oldest was 79 .
} 
Boards dominated by outside directors are likely to be more independent, bring greater breadth of experience to the firm, and be in a better position to monitor and control managers than boards dominated by inside directors. Several studies link the proportion of outside directors to board decision-making (e.g. Brickley, Coles, \& Terry, 1994; Byrd \& Hickman, 1992; Rosenstein \& Wyatt, 1990). We classify directors as insiders (employed by the firm), affiliated (e.g. former employees, family members of employees, or those with business relations with the firm), and independent (Baysinger \& Butler, 1985). We then create a variable for the percentage of outside directors serving on the board calculated as the proportion of outside directors relative to total directors on the board. We also create a variable for the percentage of outside directors serving on the compensation committee, calculated as the proportion of outside directors relative to total directors on the compensation committee. The percentage of outside directors serving on the board for the predecessor and successor are similar, averaging $62.45 \%$ and $62.13 \%$, respectively. On average the percentage of outside board members serving on the compensation committee for the predecessor and successor are similar, averaging $85.39 \%$ and $86.25 \%$, respectively.

Finally, we measure the tenure of outside directors serving on the board, which is measured as the number of years each outside director has served as a director with the firm. We then create an overall measure of outside director tenure, which is the sum the director tenure of all outside directors serving on the board. We find that on average, the tenure of outside directors serving on the board declines from 50.32 years to 48.53 years, for the predecessor and successor observation periods, respectively.

We combine these individual variables with a factor model. We first construct each board variable so that a larger value implies greater board strength. We use the variables discussed above except we use the inverse of board size and inverse of compensation committee size so that a larger value equates to a stronger board. The factor analysis produces a factor loading variable whose value ranges from -2.90 to 2.03 for the predecessor and -2.89 to 2.04 for the successor. A larger factor loading value implies a stronger board. Combining the board variables in this manner allows us to measure overall board strength in one variable. ${ }^{10}$

\subsubsection{Firm characteristics}

We use the Compustat database to obtain data on firm characteristics in year -1 and +1 . We then measure the industry-adjusted ROA (Barber \& Lyon, 1996), leverage, firm size, and Tobin's Q. Industryadjusted performance measures have been used to capture the relative performance evaluation in compensation contracts (Blackwell, Brickley, \& Weisbach, 1994; Mehran, 1995). We define the ROA as net profits divided by the book value of assets and adjusted it for the industry median using fourdigit SIC codes and three-digit SIC codes when there are not at least three other firms in the same four-digit SIC code. Our leverage measure is long-term debt divided by book value of assets, our proxy for firm size is the logarithm of the book value of assets, and we calculate Tobin's $Q$ using the method in Chung and Pruitt (1996). We find that on average firm size increases by $\$ 364.03$ million between predecessor and successor observation periods. On average, Tobin's $Q$ also increases by 0.04 between the predecessor and successor observation periods. Both of these increases are significant.

\section{Market reactions to changes in compensation structure}

We now examine whether the structure of the successor CEO's compensation contract is associated with abnormal stock returns after controlling for CEO and firm specific factors. The model we test is as follows:

$$
\begin{aligned}
\operatorname{CAR}(-1,+1)_{i t}= & \beta_{1}(\text { CEO's Equity-Based Compensation } \%)_{i t}+\beta_{k}(\text { Controls })_{i t} \\
& +\beta_{i} \sum(2 \text {-digit SIC dummy variables })_{i}+\beta_{y} \sum(\text { year dummy variables })_{t}+\varepsilon_{i t}
\end{aligned}
$$

\footnotetext{
10 We could have alternately created an index of our own from these variables, but this would have required our judgment and possible bias about which of these variables is more important in determining board strength.
} 
where the abnormal announcement return in the 3-days around the CEO succession announcement, CAR $(-1,+1)$, is a function of the successor CEO's equity-based compensation \% (measured by total equity-based compensation \%, restricted stock \%, stock options \%, or increase in equity-based compensation \%), controls (CEO Age, a dummy variable equal to 1 if the CEO also holds the title of chairman (CEO Duality), a dummy variable equal to 1 if successor CEO joined the company from the outside (New CEO is Outsider), a factor loading variable for the strength of the board (Board Strength), the log of total assets (LN Assets), long-term debt divided by book value of assets (Leverage (\%)), the industry adjusted return on assets (Ind. Adj. ROA), and (Tobin's Q), dummy variables for 2-digit SIC code and year (not reported in the tables). We compute $t$-statistics using robust standard errors clustered at the industry level (see Rogers, 1993; Wooldridge, 2002). Our primary variable of interest in Eq. (5) is the coefficient on the successor CEO's equity-based compensation \% $(E B C \%), \beta_{1}$. A finding of a negative relation between $E B C \%$ and the $C A R$ is consistent with the career concerns hypothesis (H1). However, a finding of a positive relation between $E B C \%$ and the CAR would be consistent with the retention hypothesis (H2). ${ }^{11}$

Table 3 reports results of ordinary least squares (OLS) estimates of regression Eq. (5). Regressions 1 and 4 include the total percentage of equity compensation in the successor's compensation contract and a dummy variable equal to one if the successor's compensation contract is composed of a greater percentage of equity-based pay than his predecessor, respectively. The estimated coefficients on both total equity-based compensation percentage measures are negative and significant at the $5 \%$ and $10 \%$ levels, respectively. The results suggest that a $1 \%$ increase in total equity-based compensation is associated with an average decrease in the 3-day CAR of 3.03\%. Also, those firms increasing the percentage of equity-based compensation paid to the successor CEO have 3-day CAR that average 1.3\% less than those decreasing the percentage of total equity-based compensation. Consistent with the univariate results, the negative estimated coefficients suggest that larger increases in equity-based compensation are awarded with less positive succession abnormal returns. These results support the career concerns hypothesis.

Next we divide equity-based compensation into its two primary components, restricted stock and stock options. Regressions 2 and 3 include the percentage of restricted stock and stock options for the successor, respectively. The estimated coefficient for Restricted Stock \% is negative but not significant. However, the estimated coefficient for Stock Option \% is negative and significant at the $5 \%$ level. The results suggest that a $1 \%$ increase Stock Option \% in the successor's pay contract is associated with an average decrease in the 3 -day CAR of $2.9 \%$. This result supports the career concerns hypothesis. ${ }^{12}$

Overall, our results suggest that the market reacts less favorably to CEO succession announcements where the successor CEO's contract contains a high percentage of equity-based compensation or an increase in the percentage of equity-based compensation relative to the predecessor CEO. ${ }^{13}$

\section{Evidence of career concerns}

While our results in the previous section provide support for the career concerns hypothesis, this hypothesis also predicts a more negative market reaction to increases in equity-based compensation for younger successor CEO's. The reason for this is that incoming CEO's have much stronger external

\footnotetext{
11 The negative market reaction may also be driven by the difference in compensation structure between the successor CEO's and the predecessor CEO's pay contract or suboptimal characteristics of only the predecessor CEO's contract (i.e. too little equity-based compensation). The estimated coefficients on the difference in compensation structure between the successor and predecessor are negative and significant. However, the estimated coefficients on the predecessor CEO's compensation structure are not significant. This suggests that the negative market reaction is driven by the structure of the successor CEO's pay contract. The results are reported in Appendix A.

12 The finding of only a significant market reaction to stock options may reflect the increased use of this form of equity-based compensation during our sample period. For example, while the average real (inflation-adjusted) pay package of CEOs of S\&P 500 firms more than quadrupled from $\$ 3.5$ million in 1992 to $\$ 14.7$ million in 2000 , the value of stock options granted to CEOs increased nine-fold over the same period (Hall \& Murphy, 2003).

${ }^{13}$ To test whether the market may be reacting to the dollar value of pay rather than pay structure, we include variables for total equity-based compensation in dollars (\$) and total compensation in dollars (\$). The estimated coefficients on both variables are not significant. The results are reported in Appendix A.
} 
Table 3

Market reaction to successor CEO compensation structure.

\begin{tabular}{|c|c|c|c|c|}
\hline \multirow[t]{2}{*}{ Independent variable } & \multicolumn{4}{|c|}{ Dependent variable $=\mathrm{CAR}(-1,+1)$} \\
\hline & (1) & (2) & (3) & (4) \\
\hline Total Equity-Based Comp. (\%) & $\begin{array}{l}-0.0303^{* *} \\
(-2.32)\end{array}$ & & & \\
\hline Restricted Stock (\%) & & $\begin{array}{l}-0.0136 \\
(-0.93)\end{array}$ & & \\
\hline Stock Options (\%) & & & $\begin{array}{l}-0.0292^{* *} \\
(-2.19)\end{array}$ & \\
\hline Increase in Equity Comp. (\%) & & & & $\begin{array}{l}-0.0135^{*} \\
(-1.97)\end{array}$ \\
\hline CEO Age & $\begin{array}{l}0.000222 \\
(0.40)\end{array}$ & $\begin{array}{l}0.000344 \\
(0.59)\end{array}$ & $\begin{array}{l}0.000214 \\
(0.37)\end{array}$ & $\begin{array}{l}0.000245 \\
(0.43)\end{array}$ \\
\hline CEO Duality & $\begin{array}{l}-0.00873 \\
(-1.30)\end{array}$ & $\begin{array}{l}-0.00849 \\
(-1.26)\end{array}$ & $\begin{array}{l}-0.00859 \\
(-1.27)\end{array}$ & $\begin{array}{l}-0.00955 \\
(-1.46)\end{array}$ \\
\hline CEO is Outsider & $\begin{array}{l}0.0232^{* * *} \\
(2.97)\end{array}$ & $\begin{array}{l}0.0223^{* * *} \\
(2.96)\end{array}$ & $\begin{array}{l}0.0226^{* * *} \\
(2.90)\end{array}$ & $\begin{array}{l}0.0220^{* * *} \\
(2.92)\end{array}$ \\
\hline Board Strength & $\begin{array}{l}-0.00489 \\
(-1.49)\end{array}$ & $\begin{array}{l}-0.00418 \\
(-1.29)\end{array}$ & $\begin{array}{l}-0.00534 \\
(-1.63)\end{array}$ & $\begin{array}{l}-0.00417 \\
(-1.28)\end{array}$ \\
\hline LN (Assets) & $\begin{array}{l}0.00474 \\
(1.83)\end{array}$ & $\begin{array}{l}0.00338 \\
(1.21)\end{array}$ & $\begin{array}{l}0.00468^{*} \\
(1.79)\end{array}$ & $\begin{array}{l}0.00376 \\
(1.42)\end{array}$ \\
\hline Leverage (\%) & $\begin{array}{l}0.000312^{*} \\
(1.92)\end{array}$ & $\begin{array}{l}0.000306^{*} \\
(1.95)\end{array}$ & $\begin{array}{l}0.000308^{*} \\
(1.94)\end{array}$ & $\begin{array}{l}0.000297^{*} \\
(1.82)\end{array}$ \\
\hline Ind. Adj. ROA & $\begin{array}{l}-0.0000124 \\
(-1.16)\end{array}$ & $\begin{array}{l}-0.0000119 \\
(-1.09)\end{array}$ & $\begin{array}{l}-0.0000122 \\
(-1.10)\end{array}$ & $\begin{array}{l}-0.00000969 \\
(-0.83)\end{array}$ \\
\hline Tobin's $Q$ & $\begin{array}{l}-0.00433 \\
(-1.19)\end{array}$ & $\begin{array}{l}-0.00431 \\
(-1.10)\end{array}$ & $\begin{array}{l}-0.00427 \\
(-1.17)\end{array}$ & $\begin{array}{l}-0.00420 \\
(-1.16)\end{array}$ \\
\hline 2-Digit SIC & Yes & Yes & Yes & Yes \\
\hline Year & Yes & Yes & Yes & Yes \\
\hline$N$ & 583 & 583 & 583 & 583 \\
\hline Adj. $R^{2}$ & 0.056 & 0.036 & 0.053 & 0.047 \\
\hline
\end{tabular}

Dependent variables: "CAR $(-1,+1)$ " is the dependent variable for the first six regressions and represents the CEO succession announcement cumulative abnormal return from day -1 to day +1 .

Independent variables: "Total Equity-Based Comp. (\%)" represents the successor's total equity compensation measured as a percentage of total compensation measured at year +1. "Restricted Stock (\%)" represents the successor's restricted stock grants measured as a percentage of total compensation measured at year +1 . "Stock Options (\%)" successor's stock option grants measured as a percentage of total compensation measured at year +1 . "Increase in Equity Comp. (\%)" represents a dummy variable equal to 1 if the successor's compensation contract is composed of a greater percentage of equity-based compensation than that of the predecessor at year +1 for the successor and at year -1 for the predecessor. "CEO Age" represents the CEO age at year 0 . "CEO Duality $=1$ " represents a dummy variable equal to 1 if the CEO holds the title of both CEO and Chairman of the board. "CEO is Outsider (Successor) =1" represents a dummy variable equal to 1 if the successor is an outsider and equal to 0 otherwise. "Board Strength" is a factor loading variable using factor analysis to combine \% Outside Directors, the inverse of Board Size, \# Board Meetings, Outside Director Tenure, \% Outside Directors on Comp Comm., the inverse of Comp Comm. Size, and \# Comp Comm. Meetings. "Total Assets (Mil)" represents the natural logarithm of the firm's total asset size (in millions of dollars) at year +1. "Leverage" represents the firm's leverage at year +1. "Ind. Adj. ROA" represents the firm's industry adjusted return on assets at year +1. "Tobin's $Q$ " represents the firm's Tobin's $Q$ at year +1 . All regressions include dummy variables for 2 -digit SIC and year (not reported in the tables). Robust $t$-statistics are given in parentheses.

* Indicate levels of significance of $10 \%$.

*** Indicate levels of significance of $5 \%$.

*** Indicate levels of significance of $1 \%$. 
market incentives and the optimal pay contract should therefore use a much lower percentage of equity-based pay. Thus, if the negative market reaction is due to a suboptimal incentive contract given the career concerns of the successor CEO, then we would expect a significant negative market reaction for younger CEO. ${ }^{14}$

The successor CEO's compensation contract, however, may be heavily dependent on the structure of the predecessor CEO's compensation contract in that it may be difficult for the board to make dramatic changes. According to the career concerns hypothesis the larger the difference in age between the successor CEO and the predecessor CEO, the greater the successor CEO's compensation contract may deviate from the optimal contract under this condition because the implicit incentives provided by the career concerns of the incoming (successor) CEO are considerably stronger than those of the outgoing (predecessor) CEO. To test this prediction, we create a change in CEO age variable ( $\triangle C E O$ Age) equal to the difference between the age of predecessor CEO and successor CEO, as well as an interaction variable between $\triangle C E O$ Age and equity-based compensation $\%(\triangle C E O A g e \times E B C \%)$. The model we test is as follows:

$$
\begin{aligned}
\text { CAR }(-1,+1)_{i t}= & \beta_{1}(\text { CEO's EBC \% })_{i t}+\beta_{2}(\Delta C E O \text { Age })_{i t}+\beta_{3}(\Delta C E O \text { Age } \times E B C \%)_{i t} \\
& +\beta_{k}(\text { Controls })_{i t}+\beta_{i} \sum(2 \text {-digit SIC dummy variables })_{i} \\
& \left.+\beta_{y} \sum \text { (year dummy variables }\right)_{t}+\varepsilon_{i t}
\end{aligned}
$$

where the abnormal announcement return in the 3-days around the CEO succession announcement, CAR $(-1,+1)$, is a function of the successor CEO's equity-based compensation \% (measured by total equity-based compensation \% (EBC\%), the difference in the age of the predecessor CEO and successor $\mathrm{CEO}(\triangle C E O A g e)$, an interaction variable between $\triangle C E O$ Age and equity-based compensation $\%(\triangle C E O$ Age $\times E B C \%$ ), controls (a dummy variable equal to 1 if the CEO also holds the title of chairman (CEO Duality), a dummy variable equal to 1 if successor CEO joined the company from the outside (New CEO is Outsider), a factor loading variable for the strength of the board (Board Strength), the log of total assets (LN Assets), long-term debt divided by book value of assets (Leverage (\%)), the industry adjusted return on assets (Ind. Adj. ROA), and (Tobin's Q), dummy variables for 2-digit SIC code and year (not reported in the tables). We compute $t$-statistics using robust standard errors clustered at the industry level (see Rogers, 1993; Wooldridge, 2002). Our primary variable of interest in Eq. (6) is the coefficient on the interaction variable between $\triangle C E O$ Age and equity-based compensation \% ( $\triangle C E O A g e \times E B C \%$ ), $\beta_{3}$. A finding of a negative relation between the interaction variable and the CAR is consistent with the career concerns hypothesis ( $\mathrm{H} 1$ ). However, a finding of a positive relation between the interaction variable and the CAR would be consistent with the retention hypothesis (H2).

Also, as an additional test, we examine the market reaction to equity-based pay for the successor CEO using two subsamples split at median successor CEO age. ${ }^{15}$

Table 4, Panel A, Regression 1 reports results of ordinary least squares (OLS) estimates of regression Eq. (6). The estimated coefficient on total equity-based compensation is negative and significant (at the $1 \%$ level) and the estimated coefficient on the interaction variable ( $\triangle C E O$ Age $\times E B C \%$ ) is negative and significant (at the 10\% level). The market reacts less favorably to high levels of equity-based compensation for the successor CEO and the market reaction is more negative when the change in age between the predecessor CEO and successor CEO is higher. This supports the career concerns hypothesis.

\footnotetext{
${ }_{14}$ If the negative market reaction is caused by the increased agency costs or risk-aversion effects associated with the percentage of equity-based pay, then we would not expect a negative market reaction for younger CEOs. Our results are not consistent with either of these explanations.

15 We also conduct tests using the interaction between the successor CEO's equity-based pay \% and the successor CEO's age. The estimated coefficient on the interaction term is not significant. However, CEO age may moderate the effect of CEO equity-based pay in several different ways (i.e. linear, quadratic, or step-wise). The presence of measurement error in either the independent or moderator variable may complicate the analysis and result in low power in the test of interactive effects (Baron \& Kenny, 1986). Therefore, we report results using a subsample approach to examine the moderating effect of successor CEO age. We also conduct additional tests using subsamples split at successor age ( $\leq 45,45-50,50-55,55-60$, and $>60$ years). Our conclusions are unchanged. We report the results in Appendix A.
} 
Table 4

Evidence of career concerns.

\begin{tabular}{|c|c|c|c|c|c|c|}
\hline \multirow[t]{4}{*}{ Independent variable } & \multicolumn{3}{|l|}{ Panel A } & \multicolumn{3}{|l|}{ Panel B } \\
\hline & \multicolumn{6}{|c|}{ Dependent variable } \\
\hline & \multicolumn{2}{|c|}{$\operatorname{CAR}(-1,+1)$} & \multirow[b]{2}{*}{ (3) } & \multirow[t]{2}{*}{$\mathrm{EBC} \%$} & \multicolumn{2}{|c|}{$\operatorname{CAR}(-1,+1)$} \\
\hline & (1) & (2) & & & (5) & (6) \\
\hline Total Equity-Based Comp. (\%) & $\begin{array}{l}-0.0475^{* * *} \\
(-2.81)\end{array}$ & $\begin{array}{l}-0.0347^{* *} \\
(-2.25)\end{array}$ & $\begin{array}{l}-0.0280 \\
(-1.60)\end{array}$ & & & \\
\hline Residual EBC\% & & & & & $\begin{array}{l}-0.0303^{* *} \\
(-2.54)\end{array}$ & $\begin{array}{l}-0.0472^{* * *} \\
(-2.67)\end{array}$ \\
\hline \multicolumn{7}{|l|}{ Stock (\%) } \\
\hline CEO Age & & & & $\begin{array}{l}-0.00383^{*} \\
(-1.79)\end{array}$ & & \\
\hline$\triangle$ CEO Age & $\begin{array}{l}0.000661 \\
(1.25)\end{array}$ & & & & & $\begin{array}{l}0.0000547 \\
(0.18)\end{array}$ \\
\hline $\mathrm{EBC} \% \times \Delta \mathrm{CEO}$ Age & $\begin{array}{l}-0.00198^{*} \\
(-1.73)\end{array}$ & & & & & \\
\hline Residual EBC\% $\times \Delta$ CEO Age & & & & & & $\begin{array}{l}-0.00196^{*} \\
(-1.77)\end{array}$ \\
\hline CEO Duality & $\begin{array}{l}-0.00810 \\
(-1.23)\end{array}$ & $\begin{array}{l}-0.00433 \\
(-0.40)\end{array}$ & $\begin{array}{l}-0.00828 \\
(-1.06)\end{array}$ & $\begin{array}{l}-0.0101 \\
(-0.41)\end{array}$ & & \\
\hline New CEO is Outsider & $\begin{array}{l}0.0236^{* * *} \\
(2.98)\end{array}$ & $\begin{array}{l}0.0254^{*} \\
(1.97)\end{array}$ & $\begin{array}{l}0.0181 \\
(1.55)\end{array}$ & $\begin{array}{l}0.0402 \\
(1.32)\end{array}$ & & \\
\hline Board Strength & $\begin{array}{l}-0.00526 \\
(-1.39)\end{array}$ & $\begin{array}{l}-0.00577 \\
(-1.07)\end{array}$ & $\begin{array}{l}-0.0104^{* *} \\
(-2.11)\end{array}$ & $\begin{array}{l}-0.0163 \\
(-0.89)\end{array}$ & & \\
\hline LN (Assets) & $\begin{array}{l}0.00495^{* *} \\
(2.44)\end{array}$ & $\begin{array}{l}0.00351 \\
(0.95)\end{array}$ & $\begin{array}{l}0.00503 \\
(1.20)\end{array}$ & $\begin{array}{l}0.0449^{* * *} \\
(5.98)\end{array}$ & & \\
\hline Leverage (\%) & $\begin{array}{l}0.000328^{* *} \\
(2.27)\end{array}$ & $\begin{array}{l}0.000505^{* *} \\
(2.58)\end{array}$ & $\begin{array}{l}-0.000320 \\
(-0.45)\end{array}$ & $\begin{array}{l}0.000220 \\
(0.29)\end{array}$ & & \\
\hline
\end{tabular}




\begin{tabular}{|c|c|c|c|c|c|c|}
\hline Ind. Adj. ROA & $\begin{array}{l}-0.0000121 \\
(-1.01)\end{array}$ & $\begin{array}{l}-0.0000151 \\
(-0.89)\end{array}$ & $\begin{array}{l}0.0000328 \\
(0.26)\end{array}$ & $\begin{array}{l}-0.0000158 \\
(-0.41)\end{array}$ & & \\
\hline Tobin's Q & $\begin{array}{l}-0.00425 \\
(-0.91)\end{array}$ & $\begin{array}{l}-0.00952^{* *} \\
(-2.15)\end{array}$ & $\begin{array}{l}0.0354 \\
(0.64)\end{array}$ & $\begin{array}{l}-0.00172 \\
(-0.12)\end{array}$ & & \\
\hline 2-Digit SIC & Yes & Yes & Yes & Yes & No & No \\
\hline Year & Yes & Yes & Yes & Yes & No & No \\
\hline$N$ & 583 & 304 & 279 & 583 & 583 & 583 \\
\hline Adj. $R^{2}$ & 0.063 & 0.065 & 0.038 & 0.067 & 0.016 & 0.021 \\
\hline
\end{tabular}

Dependent variables: "CAR $(-1,+1)$ " is the dependent variable for regressions 1, 2, 3, 5 and 6 and represents the CEO succession announcement cumulative abnormal return from day -1 to day +1 . "EBC \%" is the dependent variable for the regression 4 and represents the successor's total equity compensation measured as a percentage of the successor's total compensation. Independent variables: Panel A, "Total Equity-Based Comp. (\%)" represents the successor's total equity compensation measured as a percentage of total compensation measured at year +1. " $\triangle$ CEO Age" represents the difference between the successor's and predecessor's age at year 0. "EBC\% $\times \Delta$ CEO Age" is an interaction variable between "Total Equity Comp. (\%)" and " $\triangle$ CEO Age". "CEO Duality $=1$ " represents a dummy variable equal to 1 if the CEO holds the title of both CEO and Chairman of the board. "New CEO is Outsider (Successor) $=1$ " represents a dummy variable equal to 1 if the successor is an outsider and equal to 0 otherwise. "Board Strength" is a factor loading variable using factor analysis to combine \% Outside Directors, the inverse of Board Size, \# Board Meetings, Outside Director Tenure, \% Outside Directors on Comp Comm., the inverse of Comp Comm. Size, and \# Comp Comm. Meetings. "Total Assets (Mil)" represents the natural logarithm of the firm's total asset size (in millions of dollars) at year +1. "Leverage" represents the firm's leverage at year +1 . "Ind. Adj. ROA" represents the firm's industry adjusted return on assets at year +1 ."Tobin's $Q$ " represents the firm's Tobin's $Q$ at year +1 . All regressions include dummy variables for 2 -digit SIC and year (not reported in the tables). Robust $t$-statistics are given in parentheses. Regression 1 reports results for the full sample. Regression 2 reports results for successor CEO's whose age is less than the median successor CEO age. Regression 3 reports results for successor CEO's whose age is greater than the median successor CEO age.

Panel B: "Residual EBC\%" represents the residual from regression 4. "CEO Age" represents the CEO age at year 0. " $\triangle$ CEO Age" represents the difference between the successor's and predecessor's age at year 0 "Residual EBC\% $\times \triangle \mathrm{CEO}$ Age" is an interaction variable between "Residual EBC\%" and " $\triangle \mathrm{CEO}$ Age". "CEO Duality=1" represents a dummy variable equal to 1 if the CEO holds the title of both CEO and Chairman of the board. "New CEO is Outsider (Successor)=1" represents a dummy variable equal to 1 if the successor is an outsider and equal to 0 otherwise. "Board Strength" is a factor loading variable using factor analysis to combine \% Outside Directors, the inverse of Board Size, \# Board Meetings, Outside Director Tenure, \% Outside Directors on Comp Comm., the inverse of Comp Comm. Size, and \# Comp Comm. Meetings. "Total Assets (Mil)" represents the natural logarithm of the firm's total asset size (in millions of dollars) at year +1. "Leverage" represents the firm's leverage at year +1. "Ind. Adj. ROA" represents the firm's industry adjusted return on assets at year + 1 ."Tobin's $Q$ " represents the firm's Tobin's $Q$ at year +1 . All regressions include dummy variables for 2-digit SIC and year (not reported in the tables). Robust $t$-statistics are given in parentheses.

* Indicate levels of significance of $10 \%$.

** Indicate levels of significance of $5 \%$.

*** Indicate levels of significance of $1 \%$. 
Also, as an additional test, we examine the market reaction to equity-based pay for the successor CEO using two subsamples split at median successor CEO age. Regressions 2 and 3 report results reports results of ordinary least squares (OLS) estimates of regression Eq. (5) on subsamples split at median successor CEO age. Regression 2 reports results for the younger successor CEO subsample. The estimated coefficient on equity-based compensation \% is negative and significant at the $5 \%$ level. Regression 3 reports results for the older successor CEO subsample. The estimated coefficient on equity-based compensation \% is not significant. Again, the results are more consistent with the career concerns hypothesis. The market reacts less favorably to CEO succession announcements for young CEO's where the successor CEO's contract contains a high percentage of equity-based compensation.

Lastly, our career concerns hypothesis predicts that the optimal compensation contract optimizes total incentives, the combination of implicit incentives from career concerns (i.e. the labor market) and explicit incentives from the compensation contract. When implicit incentives are weakest (i.e. the CEO is near retirement), compensation should be more closely tied to performance. Conversely, when career concerns are stronger (i.e. the CEO is longer from retirement, such as with new CEOs), it may be optimal for current pay to be independent of performance. Therefore there will be a positive market reaction to increases in performance insensitive pay (i.e. salary) and a negative market reaction to increases in performance sensitive pay in the successor CEO's contract.

Overall, our results appear to support this conclusion. However, the market may also be reacting to agency problems or managerial risk-aversion effects associated with increases in equity-based pay, rather than a suboptimal incentive contract given career concerns. For example, Bebchuk, Fried, and Walker (2002) argue that high option compensation is symptomatic of a managerial-owner agency problem where managers use option compensation to camouflage the CEO's true payoff. To the extent that managers are undiversified with respect to firm-specific wealth, increasing equity-based pay may induce managers to reduce the overall risk of the firm which would likely reduce shareholder value. Guay (1999) and Ross (2004), for example, present models in which the concavity of the manager's utility function dominates the convexity of the compensation payoff inducing mangers to be more risk averse.

We address this issue by examining whether the percentage of equity-based pay in the successor CEO's pay contract is related to the contracting environment of the firm by treating the percentage of equity-based pay as a dependent variable. Specifically, if the negative market reaction to the percentage of equity-based compensation awarded to the successor CEO is due to agency problems, firms increasing the percentage of equity-based compensation in the successor CEO's pay contract might have weaker internal or external governance mechanisms.

Table 4, Panel B, regression 4, reports results of the percentage of equity-based pay on CEO characteristics, and board and firm characteristics for the successor CEO. The estimated coefficient on the successor CEO's age is negative and significant (at the $10 \%$ level). The percentage of equity-based compensation in the new CEO's pay contract is inversely related to age. The younger the successor CEO, the greater the proportion of equity-based pay in his contract. ${ }^{16}$ The estimated coefficient on board strength is not significant, suggesting that the observed increase in equity-based compensation in the successor CEO's pay contract is not likely the result of agency problems within the firm.

As a final test, we examine whether the negative market reaction to the percentage of equity-based compensation is related to excess equity-based compensation in the successor CEO's pay contract. Regression 5 reports results of ordinary least squares (OLS) estimates using the residual from firststage regressions of the percentage of equity-based pay on CEO and firm characteristics (Table 4, Panel $\mathrm{B}$, Regression 4) as a proxy for excess equity-based compensation. Again, the estimated coefficient for the residual EBC\% is negative and significant (at the $5 \%$ level). The market reacts less favorably to providing excess equity-based incentives to successor CEOs. This result supports the career concerns hypothesis. However, as a final test we also create an interaction variable between residual $\mathrm{EBC} \%$ and

\footnotetext{
$\overline{16}$ Gibbons and Murphy (1992) argue that younger CEOs would need less equity-based pay since they would be compensated in the managerial labor market with future income for good performance. We find, that on average, the younger executives receive greater equity-based pay. This may explain the negative stock market reaction associated with successions providing the new CEO with greater equity-based pay.
} 
the difference in CEO age between the predecessor CEO and successor CEO. Regression 6 reports results testing the moderating effect of change in CEO age. The estimated coefficient on the residual EBC\% is negative and significant (at the 1\% level) and the estimated coefficient on the interaction term is also negative and significant (at the $10 \%$ level). Our results suggest that younger successor CEOs receive greater equity-based compensation than older successors. However, the market reacts less favorably to firms providing younger successor CEO's with excess equity-based incentives.

Overall, our results imply that the observed negative market reaction to the percentage of equitybased pay is driven by suboptimal structuring in the compensation contract with respect to the career concerns of the CEO. The market reacts less favorably to CEO succession announcements where the successor CEO's pay contract contains a higher percentage of equity-based compensation and the CEO is younger. Of note, we also observe that the percentage of equity-based pay in the successor CEO's pay contracts is decreasing in CEO age, which suggests that boards consider retention when setting CEO pay. In practice firms load large amounts of equity-based compensation on younger CEO successors in an attempt to improve retention. However, the negative coefficient on an interaction variable testing the moderating effect of change in CEO age and the negative and significant coefficient on the equity-based compensation \% variable for younger CEO's suggests that the market reacts less favorably to this practice. Furthermore, the negative coefficient on the residual (a measure of excess compensation) suggests that this reaction is due to firms providing younger CEO's with unnecessary monetary incentives. Similarly, the market reacts less favorably to excess compensation when the change in CEO age is high. Given that younger CEO's also have high external market incentives from career concerns; our results suggest that boards should consider both internal and external incentives when setting the pay contract for new CEOs.

\section{Robustness tests}

For robustness we run several additional tests to determine if our results are driven by other factors. The results are reported in Appendix A.

\subsection{Changes in compensation structure}

Our previous regressions report results using the level of equity-based compensation in the successor CEO's pay contract as the primary independent variable. However, the market reaction may also be driven by the difference in compensation structure between the successor CEO's and the predecessor CEO's pay contract. For robustness, we rerun our results on changes rather than levels. The estimated coefficient on the change in total percentage of equity-based compensation is negative and significant, which is consistent with our previous conclusions.

\subsection{Predecessor CEO characteristics}

While we examine the level of equity-based compensation in the successor CEO's pay contract, it may also be the case that the market reaction is due to suboptimal characteristics of only the predecessor CEO's contract (i.e. too little equity-based compensation). For robustness, we rerun our results using predecessor CEO characteristics. The estimated coefficient on the total percentage of equity-based compensation is positive but not significant. The results suggest that the inverse relation between the percentage of equity-based pay in the successor CEO's pay contract and the announcement window CAR is due to the compensation contract for the incoming CEO rather than only the characteristics of the outgoing CEO's compensation contract.

\subsection{Level of compensation in dollars}

The market may be reacting to changes in the dollar value of pay rather than changes in structure (\%). Therefore, we rerun our analysis using total equity-based compensation in dollars (\$) and total compensation in dollars (\$). The estimated coefficients on both variables are not significant. 


\subsection{Extended announcement window}

We also rerun our results using a 6-day announcement window (days 0 to +5 ) to account for delays in reporting material changes in named executive officer pay contracts in an 8-k. Again, our conclusions are unchanged.

\section{Conclusion}

Gibbons and Murphy (1992) argue that in the presence of career concerns, explicit incentives (e.g. current compensation based on performance) may not be optimal. So, for executives early in their career, performance-based pay may not be the optimal form of compensation. We find evidence that although the stock market reacts favorably to succession announcements; it reacts less positively to successions in which the new CEO receives greater equity-based pay. We interpret this finding as evidence that is consistent with Gibbons and Murphy.

\section{Appendix A.}

See Table A.1 and Table A.2

Table A.1

Robustness tests of key variables.

\begin{tabular}{|c|c|c|c|c|c|}
\hline \multirow[t]{3}{*}{ Independent variable } & \multicolumn{5}{|c|}{ Dependent variable } \\
\hline & \multicolumn{3}{|l|}{$\operatorname{CAR}(-1,+1)$} & \multirow[b]{2}{*}{$(4)$} & \multirow{2}{*}{$\begin{array}{l}\operatorname{CAR}(0,+5) \\
(5)\end{array}$} \\
\hline & (1) & $(2)$ & (3) & & \\
\hline$\Delta$ Total Equity-Based Comp. (\%) & $\begin{array}{l}-0.0268^{*} \\
(-1.99)\end{array}$ & & & & \\
\hline Predecessor EBC (\%) & & $\begin{array}{l}0.0106 \\
(0.51)\end{array}$ & & & \\
\hline Successor EBC (\$) & & & $\begin{array}{l}-1.40 \times 10^{7} \\
(-0.44)\end{array}$ & & \\
\hline Successor Total Comp. (\$) & & & & $\begin{array}{l}-02.57 \times 10^{7} \\
(-0.69)\end{array}$ & \\
\hline Successor EBC (\%) & & & & & $\begin{array}{l}-0.0297^{*} \\
(-1.80)\end{array}$ \\
\hline CEO Age & $\begin{array}{l}0.000252 \\
(0.47)\end{array}$ & $\begin{array}{l}0.000345 \\
(0.59)\end{array}$ & $\begin{array}{l}0.000333 \\
(0.57)\end{array}$ & $\begin{array}{l}0.000329 \\
(0.56)\end{array}$ & $\begin{array}{l}0.000165 \\
(0.29)\end{array}$ \\
\hline CEO Duality & $\begin{array}{l}-0.00938 \\
(-1.46)\end{array}$ & $\begin{array}{l}-0.00870 \\
(-1.34)\end{array}$ & $\begin{array}{l}-0.00851 \\
(-1.26)\end{array}$ & $\begin{array}{l}-0.00865 \\
(-1.28)\end{array}$ & $\begin{array}{l}-0.00924 \\
(-1.02)\end{array}$ \\
\hline CEO is Outsider & $\begin{array}{l}0.0221^{* * *} \\
(2.90)\end{array}$ & $\begin{array}{l}0.0216^{* * *} \\
(2.96)\end{array}$ & $\begin{array}{l}0.0220^{* * *} \\
(2.93)\end{array}$ & $\begin{array}{l}0.0220^{* * *} \\
(2.94)\end{array}$ & $\begin{array}{l}0.0277^{* *} \\
(2.33)\end{array}$ \\
\hline Board Strength & $\begin{array}{l}-0.00464 \\
(-1.44)\end{array}$ & $\begin{array}{l}-0.00432 \\
(-1.36)\end{array}$ & $\begin{array}{l}-0.00444 \\
(-1.40)\end{array}$ & $\begin{array}{l}-0.00443 \\
(-1.40)\end{array}$ & $\begin{array}{l}0.000467 \\
(0.11)\end{array}$ \\
\hline LN (Assets) & $\begin{array}{l}0.00406^{*} \\
(1.70)\end{array}$ & $\begin{array}{l}0.00317 \\
(1.07)\end{array}$ & $\begin{array}{l}0.00352 \\
(1.28)\end{array}$ & $\begin{array}{l}0.00375 \\
(1.34)\end{array}$ & $\begin{array}{l}0.00368 \\
(1.31)\end{array}$ \\
\hline Leverage (\%) & $\begin{array}{l}0.000277 \\
(1.63)\end{array}$ & $\begin{array}{l}0.000291^{*} \\
(1.77)\end{array}$ & $\begin{array}{l}0.000303^{*} \\
(1.93)\end{array}$ & $\begin{array}{l}0.000300^{*} \\
(1.89)\end{array}$ & $\begin{array}{l}0.0000326 \\
(0.21)\end{array}$ \\
\hline Ind. Adj. ROA & $\begin{array}{l}-0.00000793 \\
(-0.66)\end{array}$ & $\begin{array}{l}-0.0000102 \\
(-0.86)\end{array}$ & $\begin{array}{l}-0.0000119 \\
(-1.08)\end{array}$ & $\begin{array}{l}-0.0000119 \\
(-1.07)\end{array}$ & $\begin{array}{l}-0.0000217^{*} \\
(-1.69)\end{array}$ \\
\hline
\end{tabular}

Please cite this article in press as: Elsaid, E., et al. CEO compensation structure following succession: Evidence of optimal incentives with career concerns. Quarterly Review of Economics and Finance (2009), doi:10.1016/j.qref.2009.08.004 
Table A.1 (Continued)

\begin{tabular}{|c|c|c|c|c|c|}
\hline \multirow[t]{3}{*}{ Independent variable } & \multicolumn{5}{|c|}{ Dependent variable } \\
\hline & \multicolumn{3}{|c|}{$\operatorname{CAR}(-1,+1)$} & \multirow[b]{2}{*}{ (4) } & \multirow{2}{*}{$\begin{array}{l}\text { CAR }(0,+5) \\
(5)\end{array}$} \\
\hline & (1) & (2) & (3) & & \\
\hline Tobin's $Q$ & $\begin{array}{l}-0.00393 \\
(-1.03)\end{array}$ & $\begin{array}{l}-0.00413 \\
(-1.03)\end{array}$ & $\begin{array}{l}-0.00423 \\
(-1.08)\end{array}$ & $\begin{array}{l}-0.00417 \\
(-1.07)\end{array}$ & $\begin{array}{l}0.0182^{* * *} \\
(3.42)\end{array}$ \\
\hline 2-Digit SIC & Yes & Yes & Yes & Yes & Yes \\
\hline Year & Yes & Yes & Yes & Yes & Yes \\
\hline$N$ & 583 & 583 & 583 & 583 & 583 \\
\hline Adj. $R^{2}$ & 0.059 & 0.038 & 0.036 & 0.037 & 0.049 \\
\hline
\end{tabular}

Dependent variables: "CAR $(-1,+1)$ " is the dependent variable for the first four regressions and represents the CEO succession announcement cumulative abnormal return from day -1 to day +1 . "CAR $(0,+5)$ " is the dependent variable for the fifth regression and represents the CEO succession announcement cumulative abnormal return from day 0 to day +5 .

Independent variables: “ $\Delta$ Total Equity-Based Comp. (\%)" represents the difference between the successor's total equity compensation measured as a percentage of total compensation measured at year +1 and the predecessor's total equity compensation as a percentage of total compensation measured at year -1. "Predecessor EBC (\%)" represents the predecessor's total equity compensation measured as a percentage of total compensation measured at year - 1 . "Successor EBC (\$)" represents the successor's equity-based compensation in dollars measured at year +1. "Successor Total Comp. (\$)" represents the successor’s total compensation in dollars measured at year +1 . "Successor EBC (\%)" represents the successor's total equity compensation measured as a percentage of total compensation measured at year +1 . "CEO Age" represents the CEO age at year 0 . "CEO Duality = 1 " represents a dummy variable equal to 1 if the CEO holds the title of both CEO and Chairman of the board. "CEO is Outsider (Successor) =1" represents a dummy variable equal to 1 if the successor is an outsider and equal to 0 otherwise. "Board Strength" is a factor loading variable using factor analysis to combine \% Outside Directors, the inverse of Board Size, \# Board Meetings, Outside Director Tenure, \% Outside Directors on Comp Comm., the inverse of Comp Comm. Size, and \# Comp Comm. Meetings. "Total Assets (Mil)" represents the natural logarithm of the firm's total asset size (in millions of dollars) at year +1. "Leverage" represents the firm's leverage at year +1 . “Ind. Adj. ROA" represents the firm's industry adjusted return on assets at year +1 .“Tobin's $Q$ " represents the firm's Tobin's $Q$ at year +1 . All regressions include dummy variables for 2-digit SIC and year (not reported in the tables). Robust $t$-statistics are given in parentheses.

* Indicate levels of significance of $10 \%$.

${ }^{* *}$ Indicate levels of significance of $5 \%$.

*** Indicate levels of significance of $1 \%$.

Table A.2

Robustness tests of evidence of career concerns by CEO Age.

\begin{tabular}{|c|c|c|c|c|}
\hline Sample & $N$ & (1) \%EBC & (2) \%EBC coefficient & (3) \%EBC residual \\
\hline Less than or equal to 45 & 118 & $38.44 \%$ & $\begin{array}{l}-0.0414^{* *} \\
(-2.40)\end{array}$ & $\begin{array}{l}-0.0509^{* *} \\
(-2.22)\end{array}$ \\
\hline $45-50$ & 141 & $37.56 \%$ & $\begin{array}{l}-0.0172 \\
(-0.82)\end{array}$ & $\begin{array}{l}-0.0309 \\
(-1.03)\end{array}$ \\
\hline $50-55$ & 180 & $34.55 \%$ & $\begin{array}{l}-0.0220 \\
(-1.34)\end{array}$ & $\begin{array}{l}-0.0194 \\
(-1.09)\end{array}$ \\
\hline $55-60$ & 104 & $33.26 \%$ & $\begin{array}{l}-0.0238 \\
(-1.37)\end{array}$ & $\begin{array}{l}-0.0229 \\
(-1.25)\end{array}$ \\
\hline Greater than 60 & 40 & $30.65 \%$ & $\begin{array}{l}-0.0134 \\
(-0.30)\end{array}$ & $\begin{array}{l}-0.0376 \\
(-0.73)\end{array}$ \\
\hline Less than or equal to 60 & 543 & & $\begin{array}{l}-0.0269^{* * *} \\
(-2.91)\end{array}$ & $\begin{array}{l}-0.0305^{* * *} \\
(-2.61)\end{array}$ \\
\hline Less than or equal to 65 & 570 & & $\begin{array}{l}-0.0237^{* *} \\
(-2.32)\end{array}$ & $\begin{array}{l}-0.0271^{* *} \\
(-2.22)\end{array}$ \\
\hline
\end{tabular}


Table A.2 (Continued)

\begin{tabular}{lllcc}
\hline Sample & $N$ & $(1)$ \%EBC & $(2)$ \%EBC coefficient & (3) \%EBC residual \\
\hline All & 583 & $35.57 \%$ & $\begin{array}{c}-0.0252^{* * *} \\
(-2.76)\end{array}$ & $\begin{array}{c}-0.0312^{* * *} \\
(-2.72)\end{array}$ \\
\hline
\end{tabular}

"Sample" represents the ranges of the CEO successor age ( $\leq 45,45-50,50-55,55-60$, and $>60$ years). " $N$ " represents the number of CEO succession announcements. "\%EBC" represents the successor's equity-based compensation as a percentage of the successor's total compensation. "\%EBC Coefficient" represents the coefficients for cross-sectional regressions of the CEO succession announcement CAR on the successor's total equity-based compensation. “\%BC Residual” represents the coefficients for cross-sectional regressions of the CEO succession announcement CAR on the residual from the first stage regressions of the percentage of equity-based compensation on successor CEO characteristics (Regression 7 from Table 3). Robust $t$-statistics are given in parentheses.

${ }^{* *}$ Indicate levels of significance of $5 \%$.

*** Indicate levels of significance of $1 \%$.

\section{References}

Alderfer, C. P. (1986). The invisible director on corporate boards. Harvard Business Review, 64, 38-52.

Balsam, S., \& Miharjo, S. (2007). The effect of equity compensation on voluntary executive turnover. Journal of Accounting and Economics, 43, 95-119.

Barber, B., \& Lyon, J. (1996). Detecting abnormal operating performance: The empirical power and specification of test statistics. Journal of Financial Economics, 41, 359-399.

Baron, R., \& Kenny, D. (1986). The moderator-mediator variable distinction in social psychological research: Conceptual, strategic, and statistical considerations. Journal of Personality and Social Psychology, 51, 1173-1182.

Baysinger, B., \& Butler, H. (1985). The role of corporate law in the theory of the firm. Journal of Law and Economics, 28, 179-192.

Bebchuk, L. A., \& Fried, J. M. (2004). Pay without performance: The unfulfilled promise of executive compensation. Cambridge, MA: Harvard University Press.

Bebchuk, L. A., Fried, J. M., \& Walker, D. I. (2002). Managerial power and rent extraction in the design of executive compensation. University of Chicago Law Review, 69, 751-846.

Blackwell, D., Brickley, J., \& Weisbach, M. (1994). Accounting information and internal performance evaluation: Evidence from Texas banks. Journal of Accounting and Economics, 17, 331-358.

Boeker, W., \& Goodstein, J. (1993). Performance and successor choice: The moderating effects of governance and ownership. Academy of Management Journal, 36, 172-186.

Brickley, J. A., Coles, J. L., \& Terry, R. L. (1994). Outside directors and the adoption of poison pills. Journal of Financial Economics, 35, 371-390.

Brickley, J. A., Linck, J. S., \& Coles, J. L. (1999). What happens to CEOs after they retire? New evidence on career concerns, horizon problems, and CEO incentives. Journal of Financial Economics, 52, 341-377.

Byrd, J., \& Hickman, K. (1992). Do outside directors monitor managers? Evidence from tender offer bids. Journal of Financial Economics, 32, 195-222.

Cannella, A., \& Lubatkin, M. (1993). Succession as a sociopolitical process: Internal impediments to outsider selection. Academy of Management Journal, 36, 763-793.

Chidambaran, N. K., \& Prabhala, N. R. (2003). Executive stock option repricing, internal governance mechanisms, and management turnover. Journal of Financial Economics, 69, 153-189.

Chung, K., \& Pruitt, S. (1996). Executive ownership, corporate value, and executive compensation: A unifying framework. Journal of Banking and Finance, 20, 1135-1159.

Davidson, W. N., III, Worrell, D., \& Dutia, D. (1993). The stock market effects of CEO succession in bankrupt firms. Journal of Management, 19, 517-533.

Elsaid, E., \& Davidson, W. N., III. (2009). What happens to CEO compensation following turnover and succession? Quarterly Review of Economics \& Finance, 49, 424-447.

Fama, E. F. (1980). Agency problems and the theory of the firm. Journal of Political Economy, 88, 288-307.

Gibbons, R., \& Murphy, K. J. (1992). Optimal incentive contracts in the presence of career concerns: Theory and evidence. Journal of Political Economy, 100, 468-505.

Guay, W. R. (1999). The sensitivity of CEO wealth to equity risk: An analysis of the magnitude and determinants. Journal of Financial Economics, 53, 43-71.

Hall, B., \& Murphy, K. (2003). The trouble with stock options. Journal of Economic Perspectives, 17, 51.

Holmstrom, B. (1982). Managerial incentive schemes: A dynamic perspective. In Essays in economics and management in honour of Lars Wahlbeck. HelsinkiL Swenska Handelshogkolan.

Hong, H., \& Kubik, J. D. (2003). Analyzing the analysts: Career concerns and biased earnings forecasts. Journal of Finance, 58, 313-351.

Jensen, M. (1993). The modern industrial revolution, exit, and the failure of internal control systems. Journal of Finance, 48 , 831-880.

Jensen, M. C., \& Murphy, K. J. (1990). Performance pay and top-managmenet incentives. Journal of Political Economy, 98, 225-264.

Mehran, H. (1995). Executive compensation structure, ownership, and firm performance. Journal of Financial Economics, 38, $163-184$. 
Mehran, H., \& Yermack, D. (1999). Compensation and top management turnover. Working paper, New York University.

Morgan, A. G., \& Poulsen, A. B. (2001). Linking pay to performance: Compensation proposals in the S\&P 500. Journal of Financial Economics, 62, 489-523.

Newman, H., \& Mozes, H. (1999). Does the composition of the compensation committee influence CEO compensation practices. Financial Management, 28, 41-53.

Nohel, T., \& Todd, S. (2005). Compensation for managers with career concerns: The role of stock options in optimal contracts. Journal of Corporate Finance, 11, 229-251.

Oyer, P., \& Schaefer, S. (2003). A comparison of options, restricted stock, and cash for employee compensation. Working paper, Stanford and Northwestern University.

Oyer, P., \& Schaefer, S. (2005). Why do some firms give stock options to all employees? An empirical examination of alternative theories. Journal of Financial Economics, 76, 99-133.

Parrino, R. (1997). CEO turnover and outside succession: A cross-sectional analysis. Journal of Financial Economics, 46, 165-197.

Rogers, W. H. (1993). Regression standard errors in clustered samples. Stata Technical Bulletin, 13, 19-23.

Rosenstein, S., \& Wyatt, J. G. (1990). Outside directors, board independence, and shareholder wealth. Journal of Financial Economics, 26, 175-191.

Ross, S. A. (2004). Compensation, incentives, and the duality of risk aversion and riskiness. Journal of Finance, LIX(1), $207-225$.

Sridharan, U. (1996). CEO influence and executive compensation. The Financial Review, 31, 51-66.

Toyne, M. F., Millar, J. A., \& Dixon, B. L. (2000). The relation bewteen CEO control and the risk of CEO compensation. Journal of Corporate Finance, 6, 291-306.

Vafeas, N. (1999). Board meeting frequency and firm performance. Journal of Financial Economics, 53, 113-142.

Vancil, R. (1987). Passing the baton: Managing the process of CEO succession. Boston: Harvard University Press.

Wooldridge, J. M. (2002). Econometric analysis of cross sectional and panel data. Cambridge, MA: The MIT Press.

Xie, B., Davidson, W. N., III, \& DaDalt, P. (2003). Earnings management and corporate governance: The role of the board and audit committee. Journal of Corporate Finance, 9, 295-316.

Yermack, D. (1996). Higher market value of companies with a small board of directors. Journal of Finance, 39, $185-211$. 